\title{
発声可能な人工呼吸装置について 一運動ニューロン疾患患者での応用一
}

\author{
渡 邊一夫*, 小山内 龍一* \\ 木下 正 信**，川端 五十鈴*
}

\section{A New System Enabling Both Speech and Artificially Aided Ventilation : An Application in a Patient with Motor Neuron Disease}

\author{
Kazuo Watanabe, M.D., ${ }^{*}$ Ryuichi Osanai, M.D.,* \\ Masanobu Kinoshita, M.D.,"* and Isuzu Kawabata, M.D.* \\ *Department of Otolaryngology and ${ }^{* *}$ Fourth Department of Internal Medicine, \\ Saitama Medical Center, Saitama Medical School, Saitama
}

\begin{abstract}
A new system that enables both speech and artificially aided ventilation is reported. The system consists of 1) BiPAP ${ }^{\circledR}$ (Respitronics Inc., USA), an extracorporeal artificial ventilator of the flow-triggered type, small size and light weight ; 2) a nasal pressure mask; and 3) a fenestrated tracheotomy tube (FEN type, Shiley Inc.). These instruments were applied to a 42-year-old female patient with progressive spinal muscular atrophy. She had been suffering from chronic respiratory failure, but showed no bulbar palsy. She was artificially ventilated by the BiPAP ${ }^{\circledR}$ which was connected to the inner tube of the tracheotomy tube when she was at rest. When she wished to speak, the pressure mask was firmly fixed on her nose with a rubber belt and connected to the $\mathrm{BiPAP}^{\circledR}$, the inner tracheotomy tube was extracted and the outer tracheotomy tube was inserted.
\end{abstract}

After these procedures, she could speak with a very good voice and articulation using passively expirated air through the fenestration of the tracheotomy tube.

Key words : motor neuron disease, respiratory failure, artificial ventilation, speech, quality of life

\section{I . はじめに}

筋萎縮性側索硬化症 (amyotrophic lateral sclerosis：ALS）など運動ニューロン疾患 (motor neuron disease : MND) は, その病態

*埼玉医科大学総合医療センター耳鼻咽喉科, **同. 第 4 内科

別刷請求：テ350 埼玉県川越市鴨田辻道町1981 埼玉医大総合医療センター耳鼻咽喉科 渡邊一夫

投稿受付：1995年12月 5 日
の進行により，呼吸筋の麻痺にまで症状が及ぶ こととなり, 患者は, 常に呼吸不全による死へ の恐怖に見舞われるようになる。これまでの MND を含めた神経・筋疾患の臨床においては, このような場合には, 体外式人工呼吸器による 人工換気が唯一の方策であったが，体外式人工 呼吸器の装着は, 直ちに会話によるコミュニケ ーションの喪失と, bed ridden (離床不能) の 状態を意味してきた。しかし，そのような環境 に至っても，大多数の患者は清明な意識を有し ており, 患者の生活の質 (quality of life : QOL) 
や日常生活能力 (activity of daily living: $\mathrm{ADL})$, 言い換えれば, いかに人間らしく生きら れるか，ということが医療を行うにあたって必 ず問題となってくる。

今回，われわれはこれらの問題を解決する目 的で，1）新型の小型軽量，フロートリガー方 式の体外式人工呼吸器 BiPAP $^{\circledR}$ (米国レスピト ロニクス社製)，2）加圧用鼻マスク，3) 有空 式気管カニューレ（Shiley FEN type）の 3 つ を組み合わせることにより，MND患者におい て, 人工換気と言語発声の両立とともに，患者 の行動範囲の拡大を実現できたので，ここに報 告する。

\section{II . 症例}

症 例：42歳, 女性, 小学校教員

既往症：1992年12月，第 3 腰椎分離症手術

家族歴：特記すべきことなし

経 過：1991年頃より左下肢脱力が出現し, ひきずり歩行となった。1992年11月頃より,時々 下肢の筋肉が細かく動くのを自覚し, 当院整形 外科を受診, 同年12月第 3 腰椎分離症に対し手 術を施行された。1993年 6 月頃より, 右下肢脱 力が出現し, 1994年 4 月より両上肢脱力も生じ たため当院第 4 内科を受診し，MND と診断さ れた。同年 7 月頃より，全身倦㤐感と呼吸苦を 自覚し， 8 月 31 日，呼吸困難を主訴に当院第 4 内科へ入院した。

入院時神経学的所見としては，遠位筋優位の 筋萎縮, 筋の線維束攣縮, 両側錐体路徵候がみ
られたが，球麻舫症状はなかった。針筋電図に て神経原性パターンがみられた。

以上の所見から，MND の中の脊髄性進行性 筋萎縮症 (spinal progressive muscular atrophy：SPMA）と診断された。

入院後経過：入院後, 低酸素血症および高炭 酸ガス血症を認めたことから，気管内挿管が施 行され, 従来の体外式人工呼吸器による呼吸管 理が行われた。長期にわたる人工換気が必要と 判断されたため，1994年11月18日，気管切開術 および気管孔形成術を施行された。この時点で, 患者の QOL, 特に, 本例の場合には, 意識も清 明で，知能も正常であることから，われわれは， コミュニケーションを発語により行うことに重 点をおいて，他の面においても優れた性能を持 っている体外式人工呼吸器 $\mathrm{BiPAP}^{\circledR}$, 有空式気 管カニューレ (Shiley FEN type), 加圧用鼻又 スクによる人工換気システムを考案し, 患者に 装着を試みた。

このシステムでは, 日中安静時と夜間の睡眠 中は気管カニューレに内筒を入れこれに $\mathrm{BiPAP}^{\circledR}$ を接続し，人工換気を行い(図 1，2), 患者自身が，家族，医師，看護婦等と会話を希 望する場合には，気管カニューレの内筒をはず して有空の状態とし,外筒には栓をしたうえで, 鼻周囲に密着させた加圧用マスクに $\mathrm{BiPAP}^{\circledR}$ を接続することによって，良好な発声と人工換 気の両方が得られる仕組みになっている(図 1 , $3)$ 。

このシステムにより, 人工換気と言語発声の
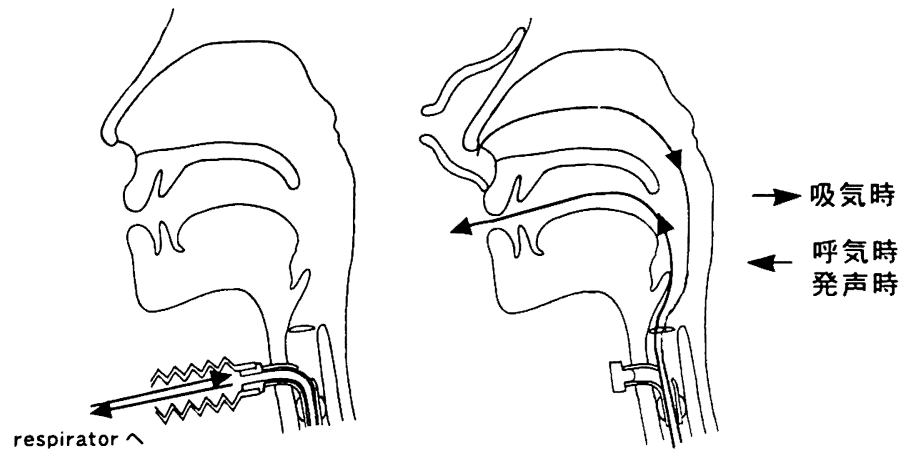

安静時

発声時

図 1 安静時と発声時の空気の流れ 


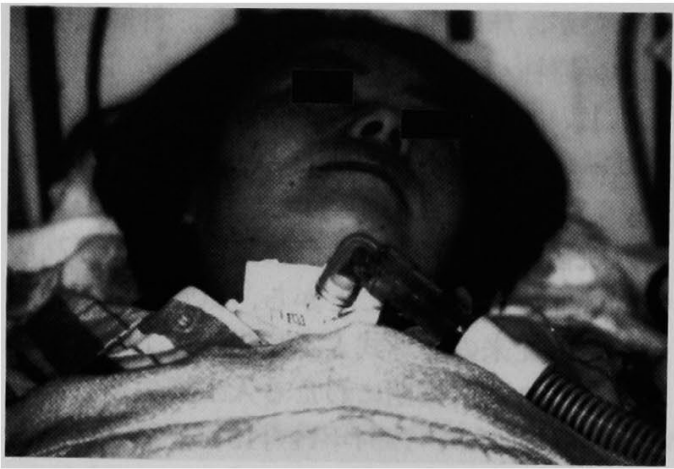

図 2 安静呼吸時

気管カニューレの内筒に $\mathrm{BiPAP}{ }^{\circledR}$ が装着されてい る。

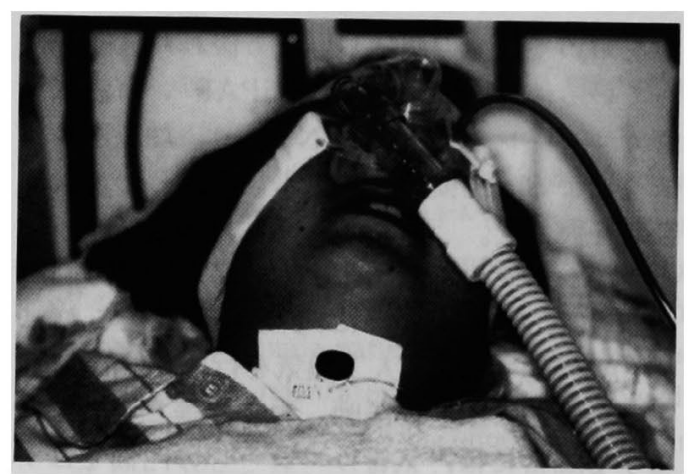

図 3 発声時

加圧用鼻マスクに BiPAP ${ }^{\circledR}$ が装着されている。気管 カニューレは栓で塞がれている。

両立という課題は, われわれの期待どおりに達 成された。さらに, BiPAP ${ }^{\circledR}$ は小型で軽量な器 具であり，バッテリーパックの使用も可能であ ることから, 本例では, 院内を車椅子で移動す ることが可能となり, さらに, この呼吸器を持 参して，一時外泊することもできた。

このように, 本例では, 新しい人工換気シス テムの使用により, 言語発声と人工換気が両立 され,さらに行動範囲も拡大された。また当然 のことではあるが, 呼吸不全での死への恐怖か ら解放され，不眠症もみられなくなった。すな わち, 身体面, 精神面の両面にわたって, QOL と ADLの向上に効果を示した。

\section{III. 考 察}

MND 症例では, 疾病自体の病態の進行によ
り呼吸不全の状態を余儀なくされる。呼吸不全 に対する医療は, 現在のところ人工換気に頼る しかないのが現状である。ところが，従来の一 般的に用いられてきた体外式人工呼吸器の使用 は, 呼吸不全は改善できるものの, 会話による コミュニケーションは不可能であった。したが って, そのような症例では, 多少なりとも指が 動かせる患者の場合には, 五十音表を 1 字 1 字 指で指し示す方法や，タイプライター等により コミュニケーションをとり，全く運動ができな い患者では, 透明なアクリル板に書かれた五十 音表を表と裏から視線をあわせ, 視線上の文字 を順に追っていく方法や，アイマークレコーダ 一を使い, 患者とのコミュニケーションを獲得 する方法などが試みられている”。しかし，これ らのいずれの方法も患者とのコミュニケーショ ンを得るには不十分な方法であり，かつ十分な コミュニケーションを得ようとすると, 長時間 を要するため, 患者本人も，また相手も，大変 な苦痛を強いられることも事実である。

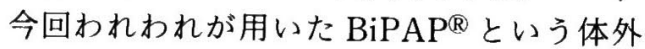
式人工呼吸装置は, 下記のような特徵を有して いる2。 1) 一般的な呼吸器が圧卜リガー方式 なのに対して, 非常に敏感 $(40 \pm 7.5 \mathrm{ml} / \mathrm{s} / 30$ $\mathrm{ms}$, 応答時間 $20 \mathrm{~ms}$ ) なフロートリガー方式で ある，2） 40～ $180 \mathrm{ml} / \mathrm{s}$ と高流量である，3） 多少の漏れも自動的に補正し, 必要な圧と気流 を維持することができる，という 3 つの特徵か ら，鼻マスクによる換気を可能にすることがで き, かつ, 意識清明な患者にとって違和感とス トレスの少ない人工換気を提供できる。同時に， 4 ）小型, 軽量であり, コストも安く, 月額数 万円でリースもできる，5) バッテリーパック を使用することにより，1〜2 時間駆動させる ことができる。また, 乗用車のシガーライター より電源を供給できる，6）一回換気量が $40 \mathrm{ml}$ 以下に低下した場合には, あらかじめ換気量, 換気回数を設定しておけば，フロートリガーモ ードから強制換気モードに自動的に切り替わる 機能があり,安全性の面でも非常に優れている。 以上の簡便性と安全性により, 院内での車椅子 等による移動や, 在宅療養にも適しているとい う特徵を有している。

一方，このシステムでは図 1 のように，口を 
閉じた後, 鼻から吸気し, 胸郭の自然の収縮を 利用して呼出，もしくは発声することになるこ とから, 口を閉じないと吸気時に圧が逃げるた め, 睡眠中は使えないという問題や, 慣れるま では多少の息苦しさを伴うため, 長時間は困難 であるという問題がある。

また,この $\mathrm{BiPAP}^{\circledR}$ の使用可能な症例は, 本 例のように球麻痺症状がみられないSPMAの ような病態の場合か, 球麻瘏症状が, 吸気の際 に十分ロを閉じられるくらいの軽度な症例のみ であり, MNDの大部分を占める ALS の進行 例では, 球麻痺症状も重篤であるために使用で きないものと思われる。

一方, SPMA と類似した病態である頸椎損傷 患者には十分使用が可能であり, その臨床応用 が今後期待される。

$\mathrm{BiPAP}^{\circledR}$ も含む最近の体外式人工呼吸器の 応用に関して注目すべき報告がある゙う。米国の ニューヨーク州においては，有資格である respiratory therapist (RT) と医師が連携し, MND 患者の在宅生活をサポートするシステムが確立 されていることが報告されている。その報告で
は，今回のわれわれが用いた鼻マスクのみなら ず, 鼻腔にはめるだけの鼻プラグ, 煙草のパイ プ様のマウスピース, 鼻マスクのまま就寝でき るロ用シール, 口鼻マスク, その他, 個人のオ ーダーメイドのマスクやピースなどを状況に合 わせて用い，在宅にて人工呼吸を受け，中には 仕事を続けたり，旅行を楽しむ人たちもいると いう。

今後, わが国においても，今回のわれわれの 使用経験や, ニューヨーク州での RT の確立の 報告を参考にしつつ, $\mathrm{BiPAP}^{\circledR}$ 等の体外式人工 呼吸器の積極的な患者への応用と, RT ての国レベルでの支援体制の整備が望まれる。

\section{文献}

1) 矢野正子：神経難病患者の共通問題に対する対 症看護。最新神経難病(宇尾野公義編著)，金原 出版, pp. 512-513, 東京, 1991.

2) $\mathrm{BiPAP}^{\circledR}$ カログ: フジ・アールシー株式会 社.

3 ) 南 良二, 石川悠加, 住谷 晋・他: ニューヨ 一ク市郊外における筋ジストロフィーの在宅人 工呼吸の現状. 平成 6 年度厚生省精神・神経疾 患研究委託費による研究報告集 ( 2 年度班・初 年度班), 国立精神・神経センター, p. 99, 1994. 